
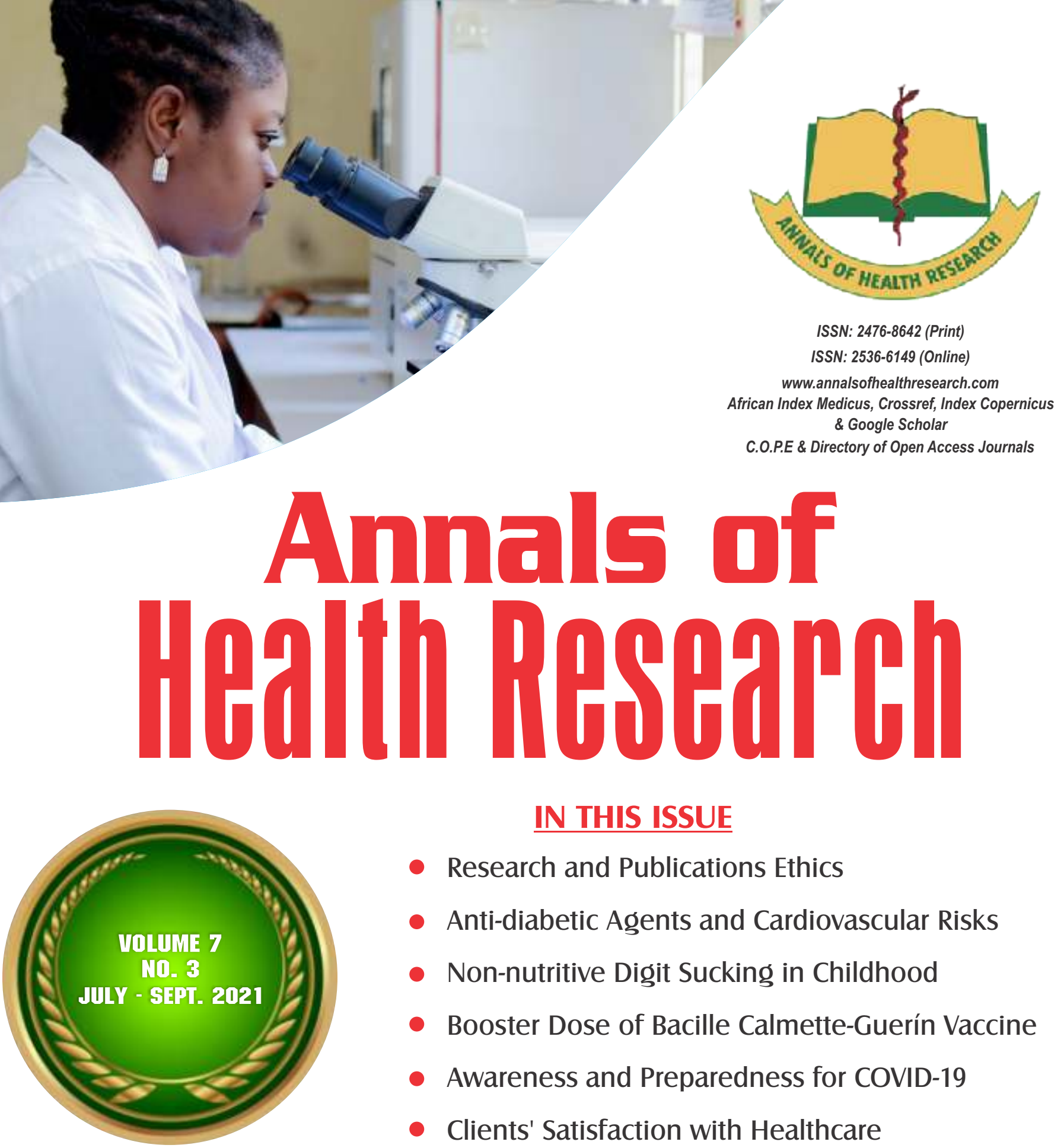

IN THIS ISSUE

- Research and Publications Ethics

- Anti-diabetic Agents and Cardiovascular Risks

- Non-nutritive Digit Sucking in Childhood

- Booster Dose of Bacille Calmette-Guerín Vaccine

- Awareness and Preparedness for COVID-19

- Clients' Satisfaction with Healthcare

- Antimicrobial Activity of Lactic Acid Bacteria

- Saddle Block for Transrectal Prostate Biopsy

- Physical and Mental Health of Stroke Survivors

- Transfusion Transmissible Infections

- Cervical Ectopic Pregnancy

PUBLISHED BY THE MEDICAL

AND DENTAL CONSULTANTS ASSOCIATION

OF NIGERIA, OOUTH, SAGAMU, NIGERIA.

www.mdcan.oouth.org.ng 


\section{Awareness and Preparedness for the Ongoing Community Spread of Coronavirus Infections Among Healthcare Workers in a Nigerian Private Tertiary Facility Ladele $\mathrm{AE}^{1}$, Ogunkoya $\mathrm{JO}^{* 2}$, Elikwu $\mathrm{CJ}^{3}$, Oyedele $\mathrm{TA}^{4}$, Tuta $\mathrm{KE}^{3}$, Abiodun $\mathrm{O}^{5}$, Idowu $\mathrm{A}^{6}$, Eigbe $\mathrm{S}^{2}$}

1Department of Family Medicine, Babcock University Teaching Hospital, Ilishan-Remo, Ogun State, Nigeria ${ }^{2}$ Division of Respiratory Medicine, Department of Medicine, Babcock University Teaching Hospital, IlishanRemo, Ogun State, Nigeria ${ }^{3}$ Department of Medical Microbiology, Babcock University Teaching Hospital, Ilishan-Remo, Ogun State, Nigeria ${ }^{4}$ Department of Surgery, Babcock University Teaching Hospital, Ilishan-Remo, Ogun State, Nigeria ${ }^{5}$ Department of Community Medicine, Babcock University Teaching Hospital, Ilishan-Remo, Ogun State, Nigeria ${ }^{6}$ Division of Endocrinology and Metabolism, Babcock University Teaching Hospital, Ilishan-Remo, Ogun State, Nigeria

*Corresponding author: Dr JO Ogunkoya, Division of Respiratory Medicine and Allergy, Department of Medicine, Babcock University Teaching Hospital, PMB 4003, Ilishan-Remo, Ogun State, Nigeria. E-mail: ogunkoyaj@babcock.edu.ng omotee4real@yahoo.com;

ORCID - https://orcid.org/0000 000284039679.

\section{Abstract}

Background: Healthcare workers (HCWs) are at high risk of contracting and spreading the novel Coronavirus Disease 2019 (COVID-19) disease putting themselves, the patients and the community at large at risk. Therefore, there is a need for adequate preparedness in the face of this pandemic.

Objectives: To assess the knowledge of HCW (clinical and non-clinical) on COVID-19, determine the level of HCWs preparedness against COVID-19 and evaluate the level of preparedness of the hospital facility against COVID-19.

Methods: Purposive sampling technique was used in this cross-sectional study. A self-administered questionnaire adapted from a validated questionnaire was used to collect appropriate data on socio-demographics, knowledge about COVID 19 and preparedness.

Results: A total of $170 \mathrm{HCWs}$ with a mean age of $34.7 \pm 6.9$ years participated in this study. More than half $(56.5 \%$; 96/170) were females. The average knowledge score among clinical staff was $9.04 \pm 13.77$, with 80 clinical staff having good knowledge of COVID-19. The majority of non-clinical staff had a fair knowledge of COVID-19 with an average knowledge score of $5.11 \pm 47.07$. About $63.4 \%$ were not confident enough in caring for a suspected coronavirus case even though more than half (57.6\%) have had formal training in Infection Prevention and Control and above 77\% (131/170) confirmed the availability of PPE in their facility. However, about three-quarters $(74.7 \% ; 127 / 170)$ believed the hospital is well prepared to manage COVID-19 cases.

Conclusion: This study revealed that this cohort of HCWs have good knowledge of COVID-19 and are convinced that they and their facility are well prepared for outbreaks of COVID-19.

Keywords: Coronavirus, COVID-19, Healthcare Worker, N95 mask, Personal Protective Equipment, SARS-CoV-2. 


\section{Introduction}

The Director-General of the World Health Organization (WHO) declared the novel Coronavirus (SARS-CoV-2) outbreak a public health emergency of international proportion on 30 January 2020. [1] On 11 March 2020, the WHO proclaimed COVID-19 a pandemic because of the rising cases and rapid spread of the virus across many continents of the world, with over 118,000 cases in 110 countries and territories worldwide. [2]

The microbe named "coronavirus" has crownlike spikes on its outer surface and has four main subtypes: alpha, beta, gamma, and delta. SARS$\mathrm{CoV}-2$ belongs to the beta coronaviruses, which are enveloped, non-segmented, single-stranded, positive-sense genomes. [3] The SARS-CoV-2 is the novel coronavirus that causes Coronavirus Disease 2019 or COVID-19. [4] It is widely believed that SARS-CoV-2 originated from bats. [5] It is also possible that pangolin or civet may be the intermediate hosts while humans are the definite hosts. [6]

COVID-19 is mainly contracted via inhalation of short-distance droplets and via direct contact. ${ }^{[7]}$ It can also be aerosolised in an enclosed or poorly ventilated space. ${ }^{[8]}$ The recently identified delta variant is about 1000 times more infectious than the earlier identified 19A/19B strains back in the initial epidemic wave of 2020. [9] The clinical spectrum of COVID-19 varies from asymptomatic or paucisymptomatic presentation to severe cases resulting in respiratory failure, which requires mechanical ventilation and intensive care supports. It may also lead to multiple organ failures and systemic complications such as sepsis and septic shock. [10] The most typical symptoms of COVID-19 include fever, fatigue, dry cough, and diarrhoea. ${ }^{[11]}$
The first case of COVID-19 in Nigeria was confirmed on 27 February 2020, and this led to the institution of stringent preventive programmes required to curb the spread of the virus by the government. [12] Prompt diagnosis, isolation, and treatment of COVID-19 cases have been shown to slow down the spread of the virus [13]; hence health workers are expected to have sufficient knowledge to make a prompt diagnosis. Also, Healthcare workers (HCWs) are at high risk of contracting and spreading the disease among themselves, their patients, and the community. [14]

From the outset of the pandemic, the WHO and the Centre for Disease Control, USA provided online courses and resource about COVID-19 for HCWs. [4, 15] These resources are constantly updated in line with the most recent scientific information and evidence. The Federal Ministry of Health and Nigeria Centre for Disease Control (NCDC) conducted workshops and seminars on COVID-19 and Infection Prevention and Control (IPC) measures. These were designed to train and equip HCWs and hospital administrators at various levels of health care delivery with knowledge and skills to improve their preparedness to achieve a more robust national response to the pandemic. ${ }^{[16]}$ Other requirements include well-trained and motivated HCWs, wellmaintained facilities, reliable supplies of medicines, hospital equipment and Personal Protective Equipment (PPE), adequate provision of funds and supportive policies. [17]

The novel coronavirus and emerging variants are causing catastrophic socio-demographic and economic damage globally. As of writing this, 169 million COVID-19 cases have been reported worldwide, and over 166,000 cases in Nigeria. [18] Curtailing the community spread of the virus is essential in mitigating the devastating impact of the pandemic. This is particularly important in 
countries and regions with weak economies and already weak health care systems, such as in West Africa. ${ }^{[19]}$ Hospitals need to anticipate and prepare for a spike in COVID-19 cases, given the ongoing community spread of the virus. Therefore, the staff should be trained to recognise signs and symptoms, known complications, and institute appropriate treatment and ensure they are well protected while doing so. [20]

HCWs should be well trained on proper donning and doffing of personal protective equipment (PPE), which includes fit testing of N95 facemasks and the use of powered air-purifying respirators and basic hand hygiene. [21] The safety of healthcare providers must be ensured. Adequate provision of PPE is just the first step; other important measures which must be instituted include avoidance of non-essential events to prioritise resources; provision of food, rest, family, and psychological support. [22] With reports of shortage of PPE in wealthy nations, developing nations such as the various parts of sub-Saharan Africa were guided on how to use, re-use and disinfect PPEs. The use of N95 masks for an extended period (continuous wearing while attending to multiple patients) is preferred to limited re-use of N95 masks (doffing and redonning between patients). [23, 24] Sanitising N95 masks with chlorine or alcohol-based solutions is unacceptable, as it damages the integrity of the material. Heating N95 masks to $70^{\circ} \mathrm{C}\left(160^{\circ} \mathrm{F}\right)$ in a dry oven for 60 minutes seems to be a promising solution, as it may disrupt viral particles and maintain mask integrity for re-use. $[25,26]$

There are many studies on awareness, perception, and preparedness for COVID-19 among health workers from different parts of sub-Saharan Africa. The outbreak of COVID-19 in hospitals will not only lead to missed opportunities to treat chronic diseases in patients with high-risk conditions, but it will also lead to high mortality rates if these patients become infected. Even patients with mild symptoms can spread SARS-CoV-2 infection to many people in the enclosed spaces of hospitals. [27] Studies in this regard are few in Nigeria, more so in the southwestern region of Nigeria, which accounts for almost half of the confirmed cases in Nigeria. [28] The objective of this study was to assess the knowledge of HCWs on COVID-19 infection, determine the level of preparedness of individual HCW and the health facility against COVID-19.

\section{Methods}

\section{Study Location}

The study was conducted at the Babcock University Teaching Hospital (BUTH), IlishanRemo, Ogun State, southwest Nigeria. Babcock University Teaching Hospital is a private tertiary hospital with a 140-bed capacity that caters for the immediate community and surrounding environs in Lagos, Ogun and Oyo States.

\section{Study Design}

The study was a cross-sectional, descriptive survey that employed a quantitative method of data collection.

\section{Study Population}

The study was carried out among the Babcock University Teaching Hospital staff, including Doctors, Nurses, Pharmacists, Housekeepers, Record Officers, Security Personnel and Administrative staff from 06 April to 18 May 2020. Excluded from the study were hospital staff older than 65 years and those on leave during the study. The research team obtained ethical approval for the study from Babcock University Health Research and Ethics Committee (BUHREC) with approval certificate number BUHREC/642/21. Verbal or written informed consent was obtained from all the study participants.

Sample size determination 
The minimum sample size of 165 for this study was determined using the formula for estimating proportions of the population where the significance level was set to 0.05 ; standard normal variate was set at 1.96 (at 95\% Confidence Interval), the absolute error of 0.05 and prevalence level of $70 \%$ (obtained from the pilot study). Therefore, to minimise errors, a total of 170 staff were studied.

\section{Sampling technique and data collection}

A purposive sampling technique was used in this study. After a pre-test, a self-administered and anonymised questionnaire adapted from a validated questionnaire was used for data collection. The questionnaire included questions about demographics, knowledge about COVID19 and preparedness. It assessed information sources, knowledge on causes, clinical features, and mode of transmission of COVID-19. It also explored training experience in Infection Prevention and Control and the knowledge and use of Personal Protective Equipment (PPE). Some of the questions required Yes-or-No responses, True-or-False responses, best option responses and some multiple-choice questions. A scoring system in which one point was awarded for every correct response to each of the questions on knowledge variables was adapted to rate the level of knowledge of COVID-19. There were 12 knowledge-based questions, and the range of scores used in determining the level of knowledge was as follows: scores 0-4, 5-8, and 912 depicting poor knowledge, fair knowledge and good knowledge, respectively. The respondents' preparedness was assessed using their knowledge of the potential risk of infection in the hospital and their level of training. In contrast, the respondents evaluated the hospital's preparedness by the respondents' perception about the provision of handwashing facilities, capacity for screening patients for COVID-19 and providing staff training, among other indices.

\section{Data Analysis}

The data were analysed using SPSS version 26 software. The data were subjected to univariate and bivariate analysis. Proportions, means and standard deviations were generated using univariate analysis. Associations between sociodemographic characteristics and knowledge of and preparedness against COVID-19 were derived using the Chi-Square test, while means and standard deviations were compared using the Student's t-test. The level of statistical significance was set at $\mathrm{p}$ values less than 0.05 .

\section{Results}

Socio-demographic characteristics

One hundred and seventy HCWs comprising 104 clinical staff and 66 non-clinical staff were studied. About two-thirds of the respondents were clinical staff made up of medical doctors (36; 21.2\%), nurses (50; 29.4\%) and laboratory scientists $(18 ; 10.6 \%)$. The non-clinical staff comprised security personnel $(28 ; 16.5 \%)$ and staff of other departments $(47 ; 27.6 \%)$, as shown in Table I.

Table I also shows the socio-demographic characteristics of the respondents. The mean age of the clinical and non-clinical staff was $21.42 \pm 27.91$ years and $35.65 \pm 26.60$ years, respectively. More than half $(43.5 \%, \mathrm{n}=98)$ of respondents were females; these comprised $57 / 104(54.8 \%)$ clinical staffs and 41/66 (62.1\%) non-clinical staffs. More than four-fifths $(88.2 \%)$ of respondents had tertiary education, about a tenth $(10.8 \%)$ had secondary education, while only $2(1.2 \%)$ had no formal education. All the clinical staff had a tertiary level of education (Table I). 
Table I: Socio-demographic characteristics of study participants

\begin{tabular}{|c|c|c|c|}
\hline \multicolumn{2}{|l|}{ Characteristics } & \multirow{2}{*}{$\begin{array}{l}\text { Clinical Staff } \\
\text { Frequency }(\%) \\
n=104 \\
10(9.6)\end{array}$} & \multirow{2}{*}{$\begin{array}{l}\text { Non-Clinical Staff } \\
\text { Frequency }(\%) \\
n=66\end{array}$} \\
\hline Age (Years) & $16-25$ & & \\
\hline & $26-35$ & $51(49.0)$ & $30(45.5)$ \\
\hline & $36-45$ & $31(29.8)$ & $21(31.8)$ \\
\hline & $46-55$ & $10(9.6)$ & $8(12.1)$ \\
\hline & $56-65$ & $2(2.0)$ & $1(1.5)$ \\
\hline \multirow[t]{2}{*}{ Gender } & Male & $47(45.2)$ & $25(37.9)$ \\
\hline & Female & $57(54.8)$ & $41(62.1)$ \\
\hline \multirow{3}{*}{$\begin{array}{l}\text { Level } \\
\text { Education }\end{array}$} & None formal & $0(0.0)$ & $2(3.0)$ \\
\hline & Secondary & $0(0.0)$ & $18(27.3)$ \\
\hline & Tertiary & $104(100.0)$ & $46(69.7)$ \\
\hline \multirow[t]{2}{*}{ Religion } & Christianity & $101(97.1)$ & $59(89.4)$ \\
\hline & Islam & $3(2.9)$ & $7(10.6)$ \\
\hline \multirow[t]{5}{*}{ Marital status } & Single & $29(27.9)$ & $35(53.0)$ \\
\hline & Married & $74(71.2)$ & $24(36.4)$ \\
\hline & Separated & $1(0.9)$ & $1(1.5)$ \\
\hline & Divorced & $0(0.0)$ & $2(3.0)$ \\
\hline & No response & $0(0.0)$ & $4(6.1)$ \\
\hline \multirow[t]{5}{*}{ Profession } & Doctors & $36(34.6)$ & \\
\hline & Nurses & $50(47.1)$ & \\
\hline & Laboratory scientists & $18(18.3)$ & \\
\hline & Security Officers & & $19(28.8)$ \\
\hline & Others & & $47(71.2)$ \\
\hline
\end{tabular}

Knowledge of COVID-19 among health care workers Table II reveals the distribution of the respondents according to their primary sources of information about COVID-19. Almost half $(45.3 \%)$ heard from international news outlets, $38.2 \%$ from social media, $7.1 \%$ from local news outlets and 3.5\% from their colleagues at work.
More than three quarter $(82.3 \%, n=140)$ of the respondents (99 clinical and 41 non-clinical staff) affirmed correctly that COVID 19 is caused by the coronavirus. Almost all $(94.1 \%$; 160/170) of the respondents (101 clinical and 59 non-clinical staff) affirmed correctly that the incubation period of coronavirus is about 14 days.

Table II: Primary sources of information about COVID-19

\begin{tabular}{lll}
\hline Response & Frequency $(\boldsymbol{n}=\mathbf{1 7 0})$ & Percentage \\
\hline Through colleagues at work & 6 & 3.5 \\
No response & 10 & 5.9 \\
Local news outlet & 12 & 7.1 \\
Through social media & 65 & 38.2 \\
International news outlet & 77 & 45.3 \\
Total & $\mathbf{1 7 0}$ & $\mathbf{1 0 0 . 0}$ \\
\hline
\end{tabular}


Most of the respondents correctly indicated that fever $(72.4 \%)$, dry cough $(65.3 \%)$ and shortness of breath $(73.5 \%)$ are the symptoms of COVID-19, but $80.6 \%$ (101 clinical and 36 non-clinical staff) incorrectly identified chest pain as a symptom of COVID-19. Concerning the mode of transmission, a majority $(85.3 \%)$ of the respondents (95 clinical and 50 non-clinical staff) correctly stated that COVID-19 could spread through coughing, sneezing, or talking with people at a distance less than a metre; 80\% (103 clinical and 33 non-clinical staff) believed it could be transmitted through contact with contaminated surfaces and above half $(51.8 \%)$ of the respondents thought it is airborne (Table III).

More than three-quarters of the respondents (86 clinical and 54 non-clinical staff) correctly listed face mask/N95 as a component of PPE. Gloves, goggles/ face shields, protective gowns, and elbow-length gloves were also listed correctly as components of PPE by $82.8 \%, 61.0 \%, 59.4 \%$ and $54.2 \%$ respondents, respectively. Only $34.7 \%$ ( $\mathrm{n}=$ 59) of the respondents ( 30 clinical and 29 nonclinical staff) knew the correct order of putting on PPE. Also, only 34.7\% knew the correct order of removing PPEs, while more than half $(58.4 \%)$ of respondents (68 clinical and 32 non-clinical staff) did not know the correct order of removing PPEs (Table III).

Eighty clinical staff had good knowledge ratings, while the majority $(37 / 66)$ of the non-clinical staff had fair knowledge ratings of COVID-19. The average knowledge score for the non-clinical staff (5.11 \pm 47.01$)$ was significantly lower than that of the clinical staff $(9.04 \pm 13.77)(\mathrm{t}=1.844, \mathrm{p}=0.033)$ as shown in Table IV.

There was no significant association between the gender of respondents and their knowledge of COVID-19 $(\mathrm{t}=4.443, \mathrm{p}=0.0001)$. Also, there was no direct relationship between the highest level of education of the respondents and knowledge of COVID-19 ( $p=0.0001)$ (Tables V). However, a significant relationship existed between the subclass of HCWs (clinical vs non-clinical) and knowledge of COVID-19 ( $p=0.033)($ Table V).

Preparedness and practices of respondents against the spread of Covid-19

Eighty per cent $(n=136)$ of the respondents, comprising 94 clinical and 42 non-clinical staff, believed that cleaning contaminated surfaces might put them at greater risks of being infected. In contrast, $31.7 \%(\mathrm{n}=54), 34.1 \%(\mathrm{n}=63), 29.5 \%$ $(\mathrm{n}=50)$ and $24.7 \%(\mathrm{n}=42)$ of both clinical and non-clinical staff believed that transportation of suspected cases of COVID-19, examination of body systems, sorting of patients in the emergency room and surgical procedures respectively may put health care workers at higher risks of contracting COVID-19 (Table VI).

Overall, a majority $(84.1 \%)$ of the respondents thought they were at high risk of infection simply because they are hospital staff. Also, 79.4\% ( $\mathrm{n}=$ 135) of the respondents stated that their routine duties and procedures put them at high risk of COVID-19 infection. About two-thirds (63.9\%, n $=108$ ) were not afraid to carry out their routine duties during the pandemic; only $36.6 \%(n=62)$ of respondents (8 clinical and 54 non-clinical staff) were confident enough to manage suspected cases of COVID-19 (Table VI).

More than half $(57.7 \%, \mathrm{n}=98)$ of the respondents (64 clinical and 34 non-clinical staff) have had formal infection prevention and control training. The majority $(52-1 \%, \mathrm{n}=89)$ of the respondents (59 clinical and 30 non-clinical staff) did not have any formal training on the use of PPE (Table VI). The mean knowledge scores of clinical staff who had training in IPC and use of PPE were $11.22 \pm 17.66$ and $10.36 \pm 16.79$, respectively. 
Table IIIa: Distribution of correct responses to the assessment of knowledge about COVID-19

\begin{tabular}{|c|c|c|c|}
\hline Knowledge Statement & $\begin{array}{l}\text { Clinical } \\
\text { Staff } \\
\text { Frequency } \\
(\%) \\
N=104\end{array}$ & $\begin{array}{l}\text { Non-Clinical } \\
\text { Staff } \\
\text { Frequency } \\
(\%) \\
N=66\end{array}$ & $\begin{array}{l}\text { Total } \\
\text { Frequency } \\
(\%)\end{array}$ \\
\hline COVID-19 is caused by coronavirus. & $99(95.1)$ & $41(62.1)$ & $140(82.3)$ \\
\hline The incubation period of coronavirus is 14 days? & $101(97.1)$ & $59(89.4)$ & $160(94.1)$ \\
\hline \multicolumn{4}{|l|}{ What are the main clinical symptoms of coronavirus? } \\
\hline Fever & $86(82.7)$ & $37(56.1)$ & $123(72.4)$ \\
\hline Dry cough & $77(74.0)$ & $34(51.5)$ & $111(65.3)$ \\
\hline Shortness breath & $96(92.3)$ & $29(43.9)$ & $125(73.6)$ \\
\hline Chest pain & $3(2.9)$ & $30(45.5)$ & $33(19.4)$ \\
\hline $\begin{array}{l}\text { There is currently no effective cure for coronavirus, but early symptom } \\
\text { detection and supportive care can help most patients recover from the } \\
\text { disease. }\end{array}$ & $102(98.1)$ & $59(89.4)$ & $161(94.7)$ \\
\hline $\begin{array}{l}\text { Severe cases of coronavirus are usually among older people and those with } \\
\text { chronic diseases. }\end{array}$ & $99(95.2)$ & $45(68.2)$ & $144(84.7)$ \\
\hline $\begin{array}{l}\text { Persons with coronavirus infection can infect others even when there are no } \\
\text { symptoms or signs of the disease }\end{array}$ & $103(99.0)$ & $61(92.4)$ & \\
\hline $\begin{array}{l}\text { Children and young adults do not need to take measures to prevent } \\
\text { coronavirus. }\end{array}$ & $102(98.1)$ & $53(80.3)$ & $155(91.1)$ \\
\hline Coronavirus is a disease of the rich. & $104(100.0)$ & $53(80.3)$ & $157(92.4)$ \\
\hline
\end{tabular}

Table IIIb: Distribution of correct responses to the assessment of knowledge about COVID-19

\begin{tabular}{|c|c|c|c|}
\hline Knowledge Statement & $\begin{array}{l}\text { Clinical Staff } \\
\text { Frequency }(\%) \\
N=104\end{array}$ & $\begin{array}{l}\text { Non-Clinical Staff } \\
\text { Frequency }(\%) \\
N=66\end{array}$ & $\begin{array}{l}\text { Total } \\
\text { Frequency }(\%)\end{array}$ \\
\hline \multicolumn{4}{|l|}{ Mode of transmission } \\
\hline Eating wild animals & $82(78.8)$ & $31(47.0)$ & $103(59.4)$ \\
\hline Contaminated surfaces & $103(99.0)$ & $33(50.0)$ & $136(80.0)$ \\
\hline Coughing, sneezing and talking at a distance less than 1 metre & $95(91.3)$ & $50(75.6)$ & $145(85.3)$ \\
\hline Airborne & $84(80.8)$ & $4(6.1)$ & $88(51.8)$ \\
\hline Body flicks & $89(85.6)$ & $27(40.9)$ & $116(68.2)$ \\
\hline \multicolumn{4}{|l|}{ Components of PPE } \\
\hline Gloves & $96(92.3)$ & $42(63.6)$ & $138(82.8)$ \\
\hline Goggle/face shields & $84(80.8)$ & $21(31.8)$ & $105(61.0)$ \\
\hline Facemask/ N95 mask & $86(82.7)$ & $54(81.8)$ & $140(82.4)$ \\
\hline Protective gowns & $70(67.3)$ & $31(47.0)$ & $101(59.4)$ \\
\hline Elbow-length gloves & $65(62.5)$ & $27(40.9)$ & $92(54.2)$ \\
\hline Hand sanitisers & $101(97.1)$ & $19(28.8)$ & $120(70.6)$ \\
\hline Colour-coded waste bin & $44(42.3)$ & $14(21.2)$ & $58(34.1)$ \\
\hline Boots & $71(68.3)$ & $11(16.7)$ & $82(47.2)$ \\
\hline The correct order of donning PPEs & $30(28.8)$ & $29(43.9)$ & $103(34.7)$ \\
\hline The correct order of doffing PPEs & $36(34.6)$ & $34(51.5)$ & $70(41.6)$ \\
\hline
\end{tabular}


Table IV: Distribution of knowledge score grades among the clinical and non-clinical respondents

\begin{tabular}{lll}
\hline Staff Categories & Knowledge Score Grades & Frequency (\%) \\
\hline $\begin{array}{l}\text { Clinical Staff } \\
\mathrm{n}=104\end{array}$ & Poor & $2(1.9)$ \\
& Fair & $22(21.2)$ \\
& Good & $80(76.9)$ \\
& Poor & $5(7.6)$ \\
$\begin{array}{l}\text { Non-Clinical Staff } \\
\mathrm{n}=66\end{array}$ & Fair & $37(56.1)$ \\
& Good & $24(36.3)$ \\
$\mathrm{t}=1.844, \mathrm{p}=0.033$ & &
\end{tabular}

Table V: Association between socio-demographic characteristics and mean knowledge score concerning COVID-19

\begin{tabular}{lllll}
\hline Variables & & $\begin{array}{l}\text { Mean } \\
\text { Knowledge } \\
\text { Score } \pm \text { SD }\end{array}$ & p-value \\
& & $1.79 \pm 27.28$ & & \\
\hline Age (Years) & $16-25$ & $8.10 \pm 11.47$ & & \\
& $26-35$ & $6.68 \pm 17.04$ & 4.443 & 0.0001 \\
& $36-45$ & $9.71 \pm 1.69$ & & \\
& $46-55$ & $9.45 \pm 0.74$ & & \\
Gender & $56-65$ & $5.07 \pm 26.22$ & & \\
& Male & $6.44 \pm 17.35$ & 0.780 & \\
Level & Female & $3.10 \pm 0.01$ & & \\
education & None formal & $14.95 \pm 73.79$ & & \\
& Secondary & $6.30 \pm 21.27$ & 3.863 & 0.0001 \\
\hline
\end{tabular}

The differences in the mean scores of trained and untrained clinical staff in the use of PPE were not statistically significant $(\mathrm{p}=0.171$ and 0.09 , respectively. The difference in the knowledge scores of trained and untrained non-clinical staff in IPC was statistically significant $(\mathrm{p}=0.005)$ (Table VII). Also, there was a positive but insignificant correlation between the level of confidence at managing suspected COVID-19 cases and the level of fear of the virus $(p=0.084)$ (Table VII).

Perception of participants on the preparedness of facility against the spread of Covid-19

More than three-quarters $(77.0 \% ; 131)$ of the respondents affirmed PPE availability in designated places at their health care facility. Also, 92.9\% ( $\mathrm{n}=158)$ and $95.8 \%(\mathrm{n}=163)$ confirmed the availability of alcohol-based sanitisers and wash hand basins with liquid soap in their health facility. Further, $92.3 \%(n=157)$ of the respondents affirmed that security officers could enforce compliance with hand hygiene guidelines. However, only $58.8 \%(\mathrm{n}=100)$ confirmed that the hospital had a triage system to sort outpatients. About three-quarters $(74.7 \%, \mathrm{n}=$ 127) of the respondents believed the hospital was well prepared to manage COVID-19 cases (Table VIII). 


\section{Discussion}

The COVID-19 pandemic has caused great health, social and economic impact. With rising cases across the globe, and the daily death toll, curbing the spread of the pandemic has become more urgent than ever. ${ }^{[34]}$ When conducting this survey, we were not aware of prior studies on this in southwest Nigeria. The majority of HCWs in this study had adequate knowledge of the cause, transmission, prevention and treatment of COVID-19. Although the average knowledge score among clinical staff was higher than that of non-clinical staff, this significant difference can be attributed to the level of information and quality of training available to these two groups.

Table VI: Preparedness and practice of HCWs against the spread of COVID-19

\begin{tabular}{|c|c|c|c|c|}
\hline Variables & Statements & $\begin{array}{l}\text { Clinical } \\
\text { Staff } \\
\text { Frequency } \\
(\%) \\
N=104\end{array}$ & $\begin{array}{l}\text { Non- } \\
\text { Clinical } \\
\text { Staff } \\
\text { Frequency } \\
(\%) \\
N=66\end{array}$ & $\begin{array}{l}\text { Total } \\
\text { Frequency } \\
(\%)\end{array}$ \\
\hline \multirow{5}{*}{$\begin{array}{l}\text { Procedures that put HCWs at } \\
\text { greater risk of COVID-19 } \\
\text { infection. }\end{array}$} & Cleaning contaminated surfaces & $94(90.4)$ & $42(63.6)$ & $136(80.0)$ \\
\hline & Transport of suspected cases & $31(29.8)$ & $23(34.8)$ & $54(31.7)$ \\
\hline & Examination of body systems & $48(46.2)$ & $15(22.7)$ & $63(37.1)$ \\
\hline & $\begin{array}{l}\text { Sorting outpatients at the emergency } \\
\text { room }\end{array}$ & $43(41.3)$ & 7 (10.6) & $50(29.5)$ \\
\hline & Surgical procedures & $39(37.5)$ & $3(4.5)$ & $42(24.7)$ \\
\hline \multirow[t]{4}{*}{$\begin{array}{l}\text { The perception of } \\
\text { respondents on COVID } 19 .\end{array}$} & $\begin{array}{l}\text { Do you think, as hospital staff, you are } \\
\text { at high risk of contracting this } \\
\text { infection? }\end{array}$ & $94(90.3)$ & $49(74.2)$ & $143(84.1)$ \\
\hline & $\begin{array}{l}\text { Does your routine work/procedures } \\
\text { put you at risk of contracting this } \\
\text { infection? }\end{array}$ & $95(91.3)$ & $40(60.6)$ & $135(79.4)$ \\
\hline & $\begin{array}{l}\text { Are you afraid of carrying out your } \\
\text { routine duties during this pandemic? }\end{array}$ & $6(5.8)$ & $56(84.8)$ & $62(36.6)$ \\
\hline & $\begin{array}{l}\text { Are you confident enough to care for a } \\
\text { suspected COVID-19 case? }\end{array}$ & $8(7.7)$ & $54(81.8)$ & $62(36.6)$ \\
\hline \multirow{7}{*}{$\begin{array}{l}\text { The perception of } \\
\text { respondents to training on } \\
\text { COVID-19. } \\
\text { If you have had any training, } \\
\text { how long ago? }\end{array}$} & $\begin{array}{l}\text { Have you had any training on } \\
\text { prevention and control? }\end{array}$ & $64(61.5)$ & $34(51.5)$ & 98 (57.7) \\
\hline & $<1$ year & $43(41.3)$ & $8(12.1)$ & $51(30.1)$ \\
\hline & $1-2$ years & $21(20.2)$ & $3(4.5)$ & $24(14.2)$ \\
\hline & $3-5$ years & $13(12.5)$ & $2(3.0)$ & $15(8.8)$ \\
\hline & $>5$ years & $6(5.8)$ & $2(3.0)$ & $8(4.8)$ \\
\hline & No response & $21(20.2)$ & $51(77.3)$ & $72(42.1)$ \\
\hline & $\begin{array}{l}\text { Have you had any formal training on } \\
\text { the use of PPE before? }\end{array}$ & $45(43.3)$ & $36(54.5)$ & 81 (47.9) \\
\hline
\end{tabular}

This finding agrees with other studies done all over the world. [29, 32, 36, 37,39] However, the average knowledge score from the present study is lower than what was reported in Pakistan [30] but higher than the scores reported in Uganda. [31] The differences in the knowledge score may be due to the larger sample sizes used in both studies and the fact that the health care workers in the 
Pakistani study had extensive COVID-19 training before the study. It is essential HCWs keep themselves abreast of new information and modifications of prior facts and figures. HCWs should also ensure they source information from authentic and reputable scientific journals and publications as there is a vast pool of diverse information, which are sometimes conflicting.

Table VII: Comparison of the mean knowledge scores on COVID-19 concerning the training of respondents on Infection Prevention and Control (IPC) and use of Personal Protective Equipment (PPE).

\begin{tabular}{llllll}
\hline Variables & Staff categories & Intervention & Mean knowledge scores \pm SD & $t$ & $p$-value \\
\hline Formal training on IPC & Clinical & Trained & $11.22 \pm 17.66$ & 1.587 & 0.057 \\
& & Untrained & $6.87 \pm 9.88$ & 2.533 & 0.005 \\
& \multirow{2}{*}{ Non-clinical } & Trained & $7.03 \pm 39.01$ & & \\
& & Untrained & $3.20 \pm 55.11$ & 0.958 & 0.171 \\
Formal training on PPE use & Clinical & Trained & $10.36 \pm 16.79$ & 1.342 & 0.090 \\
& & Untrained & $7.72 \pm 10.75$ & $6.16 \pm 31.44$ & \\
\hline
\end{tabular}

Table VIII: Perception of HCWs on the preparedness of health facility against the spread of COVID-19

\begin{tabular}{|c|c|c|c|}
\hline Statement & $\begin{array}{l}\text { Clinical Staff } \\
\text { Frequency }(\%) \\
N=104\end{array}$ & $\begin{array}{l}\text { Non-Clinical Staff } \\
\text { Frequency }(\%) \\
N=66\end{array}$ & $\begin{array}{l}\text { Total } \\
\text { Frequency } \\
(\%)\end{array}$ \\
\hline $\begin{array}{l}\text { Does your hospital have PPE in designated places } \\
\text { such as the emergency room and wards? }\end{array}$ & $100(96.2)$ & $31(47.0)$ & $131(77.0)$ \\
\hline $\begin{array}{l}\text { Alcohol-based hand sanitiser for hand hygiene is } \\
\text { readily available }\end{array}$ & 99 (95.2) & $59(89.4)$ & 158 (92.9) \\
\hline $\begin{array}{l}\text { Wash hand basins with liquid soap are readily } \\
\text { available in your hospital }\end{array}$ & 101 (97.1) & $62(93.9)$ & $163(95.8)$ \\
\hline $\begin{array}{l}\text { Security officers are readily available to ensure } \\
\text { compliance with hand hygiene }\end{array}$ & $100(96.2)$ & 57 (86.4) & $157(92.3)$ \\
\hline $\begin{array}{l}\text { Does your hospital have a triage system in sorting out } \\
\text { the patients in a waiting area/place? }\end{array}$ & $63(60.6)$ & 37 (56.1) & $100(57.0)$ \\
\hline $\begin{array}{l}\text { Is the hospital prepared to manage COVID } 19 \\
\text { patients? }\end{array}$ & 98 (94.2) & $29(43.9)$ & $127(74.7)$ \\
\hline
\end{tabular}

In the present study, most of the respondents had formal training on preventing and controlling the novel coronavirus. The number of respondents who had IPC training in the present study is lower than the numbers in the Uganda [32] and the UAE [36] studies in which about $87.9 \%$ were adequately trained in IPC but much higher than the finding in the Libyan study, ${ }^{[31]}$ which showed that only $7 \%$ of HCWs were trained. Hospitals should have an active infection and prevention control unit manned by infectious disease specialists who will help draft policies, develop models for disease outbreaks and enforce compliance with IPC policies. There should also be training and retraining of staff, with timely updates and periodic assessments.

Staff preparedness was assessed in terms of activities and engagements that put them at high risk or help mitigate the risk of getting infected. 
Such activities include routine job and occupational hazards such as cleaning contaminated surfaces, transporting suspected cases, examining body systems, sorting outpatients in the emergency room, and surgical procedures. This study revealed that the majority of HCWs believed they were at high risk of being infected with COVID-19 and believed that their routine work/procedures put them at risk of being infected. These findings are similar to what was reported in the Egyptian study. Risk perception among HCWs was high, with $89 \%$ of the respondents believing they are more susceptible to COVID-19 than others. [37] Furthermore, just about a quarter $(25.9 \%)$ of the HCWs in the present study are confident of managing suspected cases of COVID-19, but this is lower than the finding of $57 \%$ in Ghana. ${ }^{[33]}$ This may be the effect of social media misinformation on COVID-19, where the spread of the coronavirus infection has been misrepresented and wrongly labelled perceived to be a death sentence.

In the present study, about two-thirds of the respondents expressed fear in taking care of suspected cases of COVID-19; this can be compared to $83 \%$ of health workers expressing fear of getting infected with coronavirus in a cross-sectional survey in Egypt. [37]. This low confidence with a high rate of fear can heighten psychological stress and impact HCWs response. More intentional efforts must be made to support HCWs' emotional and mental health. [35]

The hospital's preparedness was assessed through the perception of HCWs regarding the provision of handwashing facilities, screening of patients and training for staff, among other indices. Most of the respondents affirmed that facilities for hand hygiene were available in the facility. This is comparable to the findings in studies done in Ghana [33] and in Benin, Nigeria [39], in which more than $70 \%$ of the respondents were satisfied with the availability of hand sanitisers and hand dryers within the facility and over half were satisfied with the availability of handwashing stations at various points of care.

In the present study, the most available components of PPE were facemasks, followed by gloves, alcohol-based sanitisers, goggles and protective gowns. The availability of PPE has been a major crisis across hospitals the world over. This finding is similar to a study done at a Central Hospital in Malawi [40], which revealed that PPE was available in $75.8 \%$ of the wards. The most inaccessible PPEs were goggles and footwear, while facemasks, sterile and non-sterile gloves and aprons were readily accessible. [38] Most of the participants in the present study believed the hospital is well prepared to manage cases of COVID-19 because steps were taken to put in place measures needed to mitigate and treat outbreaks of this infection. This finding is similar to that in the UAE, in which almost threequarters believed the country was well prepared to manage cases of COVID-19. $\{36\}$

Study Limitation: The purposive sampling methods for this study may have led to a high level of bias and limit the ability to generalise research findings to all HCWs.

\section{Conclusion}

This study revealed that this cohort of Nigerian HCWs had good knowledge of COVID-19 and was convinced they were well prepared for outbreaks of COVID-19. They also affirmed that their health care facility was equally well prepared for a surge in the incidence of COVID19. This study showed that the knowledge of COVID-19 and training in Infection Prevention and Control should be strengthened to defeat the menace of COVID-19 in all healthcare facilities nationwide. However, health administrators and health planners need to continue to provide all the required resources to allow HCWs to carry 
out their important roles to combat COVID-19 while working in a safe environment.

Declaration: The listed authors are members of the BUTH COVID-19 Task Force, Babcock University Teaching Hospital, Ilishan-Remo, Nigeria.

Acknowledgement: The authors express their sincere appreciation to the Chief Medical Director of Babcock University Teaching Hospital, Ilishan-Remo, Ogun State, Nigeria and his team for their support.

Authors' Contributions: All the authors participated in the conception and design of the study, literature review, data analysis and interpretation, drafting of the manuscript and review of the draft manuscript for sound intellectual content. All the authors approved the final version of the manuscript.

Conflict of Interest: None.

Funding: Self-funded.

Publication History: Submitted 09 June 2021; Accepted 27 August 2021.

\section{References}

1. IHR Emergency Committee on Novel Coronavirus (2019-nCoV). https://www.who.int/dg/speeches/detail/ who-director-general-s-statement-on-ihremergency-committee-on-novelcoronavirus-(2019-ncov) Accessed 02 August 2020.

2. Cucinotta D, Vanelli M. WHO Declares COVID-19 a Pandemic. Acta Bio-Medica Atenei Parm 2020; 91: 157-160. https://doi.org/10.23750/abm.v91i1.9397

3. Khan MM, Noor A, Madni A, Shafiq M. Emergence of novel coronavirus and progress toward treatment and vaccine. Rev Med Virol $\quad 2020 \quad$;30: $\quad$ e2116. https://doi.org/10.1002/rmv.2116.

4. CDC. Coronavirus Disease 2019 (COVID-19). Centers for Disease Control and Prevention $11 \quad$ February 2020. https://www.cdc.gov/coronavirus/2019ncov/hcp/training.html.
5. Zhou P, Yang XL, Wang XG, Hu B, Zhang L, Zhang $\mathrm{W}$, et al. A pneumonia outbreak associated with a new coronavirus of probable bat origin. Nature 2020; 579: 270273. https://doi.org/10.1038/s41586-0202012-7.

6. Lam TTY, Jia N, Zhang YW, Shum MH, Jiang $\mathrm{JF}$, Zhu HC, et al. Identification of 2019-nCoV related coronaviruses in Malayan pangolins in southern China. BioRxiv 2020; 02: 94549485.

https://doi.org/10.1101/2020.02.13.945485.

7. Lee PI, Hsueh PR. Emerging threats from zoonotic coronaviruses-from SARS and MERS to 2019-nCoV. J Microbiol Immunol Infect 2020; 53: 365-367. https://doi.org/10.1016/j.jmii.2020.02.001.

8. Anderson EL, Turnham P, Griffin JR, Clarke CC. Consideration of the Aerosol Transmission for COVID-19 and Public Health. Risk Anal. 2020; 40: 902-907. https://doi.org/10.1111/risa.13500.

9. Zhang M, Xiao J, Deng A, Zhang Y, Zhuang $\mathrm{Y}, \mathrm{Hu} \mathrm{T}$, et al. Transmission dynamics of outbreak of the COVID-19 Delta variant B.1.617.2 - Guangdong Province, China, MayJune 2021. China CDC Weekly 2021; 3: 584586.

https://doi.org/10.46234/ccdcw2021.148

10. Cascella M, Rajnik M, Cuomo A, Dulebohn SC, Di Napoli R. Features, Evaluation and Treatment Coronavirus (COVID-19), in StatPearls, Treasure Island (FL): StatPearls Publishing, 2020.

11. Hassan SA, Sheikh FN, Jamal S, Ezeh JK, Akhtar A. Coronavirus (COVID-19): A Review of Clinical Features, Diagnosis, and Treatment. Cureus 2020; 12. https://doi.org/10.7759/cureus.7355.

12. "Nigeria confirms first coronavirus case." BBC News 202028 February. Cited April 2021. 
13. Hellewell J, Abbott S, Gimma A, Bosse NI, Jarvis CI, Russell TW, et al. Feasibility of controlling COVID-19 outbreaks by isolation of cases and contacts. Lancet Global Health 2020; 8: e488-e496. https://doi.org/10.1016/S2214109X(20)30074-7.

14. Semple S, Cherrie JW. Covid-19: Protecting Worker Health. Ann Work Expo Health 2020; 64: $\quad$ 461-464. https://doi.org/10.1093/annweh/wxaa033.

15. WHO. Coronavirus disease (COVID-19) training: Online training. https://www.who.int/emergencies/disease s/novel-coronavirus-2019/training/onlinetraining Accessed 13 October 2022.

16. Federal Ministry of Health. Stakeholder Engagement Plan [Online]. Available: https://health.gov.ng/doc/Nigeria-COVID19-Stakeholder-Engagement-Plancleared.pdf Accessed 13 October 2020.

17. Paintsil E. COVID-19 threatens health systems in sub-Saharan Africa: the eye of the crocodile. J Clin Invest 2020; 130: 2741-2744. https://doi.org/10.1172/JCI138493.

18. “COVID-19 Map," Johns Hopkins Coronavirus Resource Center. https:/ / coronavirus.jhu.edu/map.html Accessed 04 August 2020.

19. Taboe HB, Salako KV, Tison JM, Ngonghala CN, Kakaï RG. Predicting COVID-19 spread in the face of control measures in West Africa. Math Biosci 2020; p. 108431. https://doi.org/10.1016/j.mbs.2020.108431.

20. "WHO-COVID-19-

Community_Transmission-2020.1-eng.pdf." Accessed 04 August. 2020. [Online].
Available:

https://apps.who.int/iris/bitstream/handle /10665/331421/WHO-COVID-19-

Community_Transmission-2020.1-eng.pdf.

21. Chopra V, Toner E, Waldhorn R, Washe L. How Should U.S. Hospitals Prepare for Coronavirus Disease 2019 (COVID-19)? Ann Intern Med 2020; 172: 621-622. https://doi.org/10.7326/M20-0907.

22. PubMed Central Link. Accessed 24 August 2020. [Online]. Available: https://www.ncbi.nlm.nih.gov/pmc/article s/PMC7138074/.

23. Fisher EM, Shaffer RE. Considerations for recommending extended use and limited reuse of filtering facepiece respirators in health care settings. J Occup Environ Hyg 2014; 11: D115-D128. https://doi.org/10.1080/15459624.2014.9029 54

24. CDC. Coronavirus Disease 2019 (COVID-19). Centers for Disease Control and Prevention $2020 \quad 11 \quad$ February. https://www.cdc.gov/coronavirus/2019ncov/hcp/respirators-strategy/index.html Accessed 13 October 2020.

25. A Scientific consortium for data-driven study of N95 filtering facepiece respirator decontamination.

https://www.n95decon.org (Accessed 13 October 2020.

26. University of Tennessee Research Foundation.

https://utrf.tennessee.edu/informationfaqs-charged-filtration-materialperformance-after-various-sterilizationtechniques/ Accessed 13 October 2020.

27. Mossa-Basha M, Meltzer CC, Kim DC, Tuite MJ, Kolli KP, Tan BS. Radiology Department Preparedness for COVID-19: Radiology Scientific Expert Review Panel. Radiology 2020; 296: E106-E112. https://doi.org/10.1148/radiol.2020200988. 
28. NCDC Coronavirus COVID-19 Microsite. https://covid19.ncdc.gov.ng/\#! Accessed 05 August 2020.

29. Zhang M, Zhou M, Tang F, Wang $Y$, Nie H, Zhang L, et al. Knowledge, attitude, and practice regarding COVID-19 among healthcare workers in Henan, China. J Hosp Infect 2020; 105:183-187. https://doi.org/10.1016/j.jhin.2020.04.012.

30. Saqlain M, Munir MM, Rehman SU, Gulzar A, Naz S, Ahmed Z, et al. Knowledge, attitude, practice and perceived barriers among healthcare workers regarding COVID-19: a cross-sectional survey from Pakistan. J Hosp Infect 2020; 105: 419-423. https://doi.org/10.1016/j.jhin.2020.05.007.

31. Olum R, Chekwech G, Wekha G, Nassozi D R, Bongomin F. Coronavirus Disease-2019: Knowledge, Attitude, and Practices of Health Care Workers at Makerere University Teaching Hospitals, Uganda. Front Public Health 2020; 8. https://doi.org/10.3389/fpubh.2020.00181.

32. Elhadi M, Msherghi A, Alkeelani M, Zorgani A, Zaid A, Alsuyihili A, et al. Assessment of Healthcare Workers' Levels of Preparedness and Awareness Regarding COVID-19 Infection in Low-Resource Settings. Am J Trop Med Hyg 2020; 103: 828-833. https://doi.org/10.4269/ajtmh.20-0330.

33. Nkansah M, SerwaaD, Adarkwah LA, OseiBoakye F, Mensah K, Tetteh P, Awulu S, Apodola A. Novel coronavirus disease 2019: knowledge, practice and preparedness: a survey of healthcare workers in the OffinsoNorth District, Ghana. Pan Afr Med J 2020; 35 (Suppl 2): 79. https://doi.org/10.11604/pamj.supp.2020.3 5.2.23644.
34. Safe hospital preparedness in the era of COVID-19: The Swiss cheese model | Elsevier Enhanced Reader. https://reader.elsevier.com/reader/sd/PII/ S1201971220305294?token=36C8E4B6998045 D2CE01DC30D691C66E4C5FF26C91960FFB4 61FC768148F2B218574F2A22E4DB0E47C9F2 4DD5F5D2C4F. Accessed 10 April 2021.

35. Lee IK, Wang CC, Lin MC, Kung CT, Lan KC, Lee CT. Effective strategies to prevent coronavirus disease-2019 (COVID-19) outbreak in hospital. J Hosp Infect 2020; 105: 102-103. https://doi.org/10.1016/j.jhin.2020.02.022.

36. Dalky HF, Ghader N, Al Kuwari M, Alnajar M, Ismaile S, Almalik M, et al. Assessment of the Awareness, Perception, Attitudes, and Preparedness of Health-care Professionals Potentially Exposed to COVID-19 in the United Arab Emirates. J Multidisc Healthcare 2021; $\quad$ 14: 91-102. https://doi.org/10.2147/JMDH.S278479

37. Wahed WYA, Hefzy EM, Ahmed MI, Hamed NS. Assessment of Knowledge, Attitudes, and Perception of Health Care Workers Regarding COVID-19, A Cross-Sectional Study from Egypt. J Community Health 2020; 45: 1242-1251. https://doi.org/10.1007/s10900-020-008820 .

38. Gebreselassie AF, Bekele A, TatereI HY, Wong R. Assessing the knowledge, attitude and perception on workplace readiness regarding COVID-19 among health care providers in Ethiopia-An internet-based survey. PLoS ONE 2021; 16. https://doi.org/10.

34740/kaggle/dsv/1820578

39. Ogboghodo EO, Nwaogwugwu JC, Obarisiagbon OE, Omo-Ikirodah OT, Uwugiaren EI, Akoria OA, et al. Health Facility Preparedness and Response to COVID-19: An Assessment of Employee Satisfaction in a Teaching Hospital in 
Southern Nigeria. Cent Afr J Public Health 2020;

6:

https://doi.org/10.11648/j.cajph.20200605.1

2.

40. Madziatera D, Msofi KS, Phiri TV, Mkandawire SD, Comber A. Availability,
Accessibility and Proper Use of Personal Protective Equipment in Wards at Queen Elizabeth Central Hospital (QECH) Blantyre, Malawi: An Observational Study. Malawi Med J. 2020; 32: 124-131. https://doi.org/10.4314/mmj.v32i3.4



is an Open Access document licensed for distribution under the terms and conditions of the Creative Commons Attribution License (http://creativecommons.org/licenses/by-nc/4.0). This permits unrestricted, non-commercial use, reproduction and distribution in any medium provided the original source is adequately cited and credited. 